\title{
Change of evaporations leads to climate change
}

\section{Introduction}

The basis of all floods and droughts is water, its excess in some places and lack of it in others. Both here and there the biota dies. Water is the main mediator, means and condition for the existence of life on the planet. Water accumulates in the clouds, moves, precipitates, dissolves minerals and organic matter in itself, delivers it to animals and plants. Water itself is not a product, it is a supplier, component and builder of cells, matter of all biota. Each plant species and a living organism, and within each species, each individual has his own personal ability to extract the substances dissolved in it. And water does not disappear, it is contained in every cell of the body and leaves the body after performing its functions in the form of exhalation, excretions, sweat, transpiration of plants have their own specific individual properties. The structure of each type of discharge is strictly individual and has its own purpose. This is how we feel the fragrance of flowers when inhaled; animals smell their victims and partners by smell. Exhalation and urine doctors diagnose diseases. All of these secretions are concentrated in the atmosphere and are called aeroplankton. " "American microbiologist Parker found that air contains a large amount of organic matter and a variety of microorganisms, including algae, some of which are active. The temporary location of these organisms can be, for example, cumulus clouds. Acceptable for the flow of vital processes temperature, water, trace elements, radiant energy - all this creates favorable conditions for photosynthesis, metabolism and cell growth. According to Parker, "clouds are living ecological systems," giving multicellular microorganisms the opportunity to live and multiply. "From this it can be assumed that this plankton is formed into a single substance and creates a special mechanism that programs the volumes, terms and places of precipitation, forms special clouds. The volume of water in the balance, the composition of the substance and the cycle time cycle corresponds to all biota on the planet. The symbiosis of biota and the water cycle over millions of years has built a graph of the distribution of moisture the amount, time and place of precipitation. It was these conditions that led to the creation of various arid zones in terms of volumes and cycles of water rotation - deserts and tropics, forests and steppes were formed. The allocation of moisture and waste of the animal and plant worlds is the most important link in the circuit. Processing time and the movement of water in food chains, and the release of waste has a certain pattern and duration. For example, drunken water, being processed in the lungs, mixing with air in the lungs, comes out with an exhalation after a few minutes, and the other part of the water enters other organs, is converted into blood, muscles, bones, and other body tissues and is released in months and years. For example, from the bones after the death of the subject. All biota accumulates moisture in itself and releases waste with distribution by time, portions and quality.

The development of our civilization has destroyed a significant part of the biota almost 70 percent of the land we used for arable land, mines, landfills, asphalt, artificial reservoirs, cut down forests. A man who uses water not only and not so much for drinking, but as a tool for the production of material goods, comfort, many different needs, has become a working body, a tool in many technological processes, where only its physical and chemical properties are used. Changing and destroying its chemical composition, for example, removing salts before boiling and heating in heat exchangers, in water treatment
Volume 8 Issue I - 2019

\author{
Oleg Halidullin \\ Kazakh National University, Alb-Farabi, Russia
}

Correspondence: Oleg Halidullin, Kazakh National University, Junior researcher Alb-Farabi, Russia, Email 71 15215@mail.ru

Received: January 02, 2019 | Published: January 30, 2019

systems, we use it in many processes. It is washing, cooling, boiling, transportation, energy production and other uses in production, agriculture and municipal processes. After them, the water evaporates directly and after discharge into the sewers and rivers. As a result of industrialization, humanity is increasing its water consumption for these purposes at an increasing rate. Almost all waters taken from nature by man have lost their natural functions, their natural meaning. The historical process of processing evaporation in the atmosphere, the formation and distribution of cloud systems, broke down. Precipitation began to fall in other volumes, not in the former places, not in the periods specified by nature. Often, they fall in such volumes that overflow rivers and flood large areas with floods. Or in such reduced amounts that everything dries up and fires begin. This is confirmed by recent studies.

At present, according to new analyzes of data collected at meteorological stations around the world, half of the precipitation a year falls in just 12 days. By the end of the century, climate models predict that this one-sided distribution of rain and snow is likely to become even more asymmetric, and half of the annual precipitation will fall in 11 days. These results were published in geophysical research letter from the Journal of the American Geophysical Union. ${ }^{2}$

Currently, in 2018, the water cycle on the surface of the Earth consists of $520,000 \mathrm{~km}^{3}$ of water. At the same time, $109,000 \mathrm{~km}^{3}$ a year falls on the continents, and $72,000 \mathrm{~km}^{3}$ or 72 trillion tons evaporates, the rest flows into the seas and oceans. ${ }^{3}$

The officially accepted hypothesis of climate change found the culprit - carbon dioxide. According to UN experts, the increase in $\mathrm{CO}_{2}$ emissions ranged from 0.5 to $5 \%$ per year. As a result, over the past hundred years, 400 billion tons of carbon dioxide has just entered the atmosphere due to the burning of fuel. ${ }^{4}$ On average, over a hundred years -4 billion tons per year. We divide by 2.2 trillion by 4 billion, we get 18,000 . It is eighteen thousand times that evaporation exceeds carbon dioxide emissions in terms of volumes lifted into the atmosphere in 1 year. In other words: the atmosphere accepts 1 part of $\mathrm{CO}_{2}$ and 18000 parts of water vapor. Only from this alone, it can be concluded that the effects on climate and weather produce more water evaporation, and not $\mathrm{CO}_{2}$. Each of us feels this on an overcast day.

According to the data of, ${ }^{5}$ annually mankind extracts up to 20 thousand cubic kilometers of groundwater for its needs. Plus, according to ${ }^{6}$ people irrevocably take away about 2 thousand cubic kilometers of fresh water from rivers and lakes. Annually all this water through pipes and channels goes into another redistribution. Redistribution of unnatural consumption. Washing sewage into the sewage system, water solutions of a wide variety of chemical and biological substances - from household chemicals to residues of petroleum products during washing, to pesticides from the fields. Sewage is drained to septic 
tanks and rivers. Water molecules react with molecules of a multitude of chemicals and organics, and, for sure, they take something into the atmosphere when they evaporate. Such an assumption can be made if we take into account the appearance of acid rain. Maybe they do not capture, but their own quality, structure is not the same as that of vapor molecules exhaled by biota. Evaporation from drying washed things - dishes, linen, asphalt, from coolers and evaporators of many factories, from the surfaces of sumps, nature is not provided. All such evaporations can be safely called artificial evaporations. Research on the quality of evaporation from biota and artificial evaporation was not found. This is just an assumption, a hypothesis and, as each hypothesis, needs proof. Studying the issue is quite simple, but very important - it determines the differences between organic and artificial fumes, can provide a fundamental basis for conclusions about the role of water in climate change. And a real means of preserving and restoring climate.

Without focusing on the quality of evaporation, it is necessary to pay attention to the quantitative and temporal parameters of evaporation. To these should be added and the total evaporation from degraded areas - landfills, arable land, reservoirs. The precipitation they do not find their natural consumers and evaporate without structural changes - what came, then went. Significant amounts of destruction of water molecules occur directly in the air by a variety of internal combustion engines, compressors, all furnaces and heaters. Each volume of atmospheric air contains water in a molecular state. According to the information ${ }^{7}$ The absolute humidity of air - the amount of water vapor contained in the air, expressed in grams per cubic meter, is sometimes also called the elasticity or density of water vapor. At a temperature of $0^{\circ} \mathrm{C}$, the absolute humidity of saturated air is $4.9 \mathrm{~g} / \mathrm{m}^{3}$. In equatorial latitudes, the absolute humidity of the air is about $30 \mathrm{~g} / \mathrm{m}^{3}$, and in the polar regions $0.1 \mathrm{~g} / \mathrm{m}^{3}$ (Figure 1 ).

When this steam enters the burner of the furnace or cylinders of engines, compressors, this moisture does not burn, does not disappear. It changes its structure and after the exhaust joins the artificial vapors. How many planes fly around the world, crossing the clouds, how many ocean-going ships in the world draw in air with moisture from the surface of the oceans. On average, a plane that has flown by for 1 hour burns about 50 tons of air.

It is assumed that the total volume of artificial evaporation has become commensurate with the total evaporation of land and has reached a critical level in terms of the volume and cycle time of the circuit. The mechanism of natural transformations broke down in the troposphere. Nature had no such amount of evaporation before, before the development of civilization. There was a transition from quantity to quality. The new substance of the clouds has led to new atmospheric phenomena - to new for nature actions in the troposphere. So unusual clouds appeared (Figure 2). ${ }^{8}$

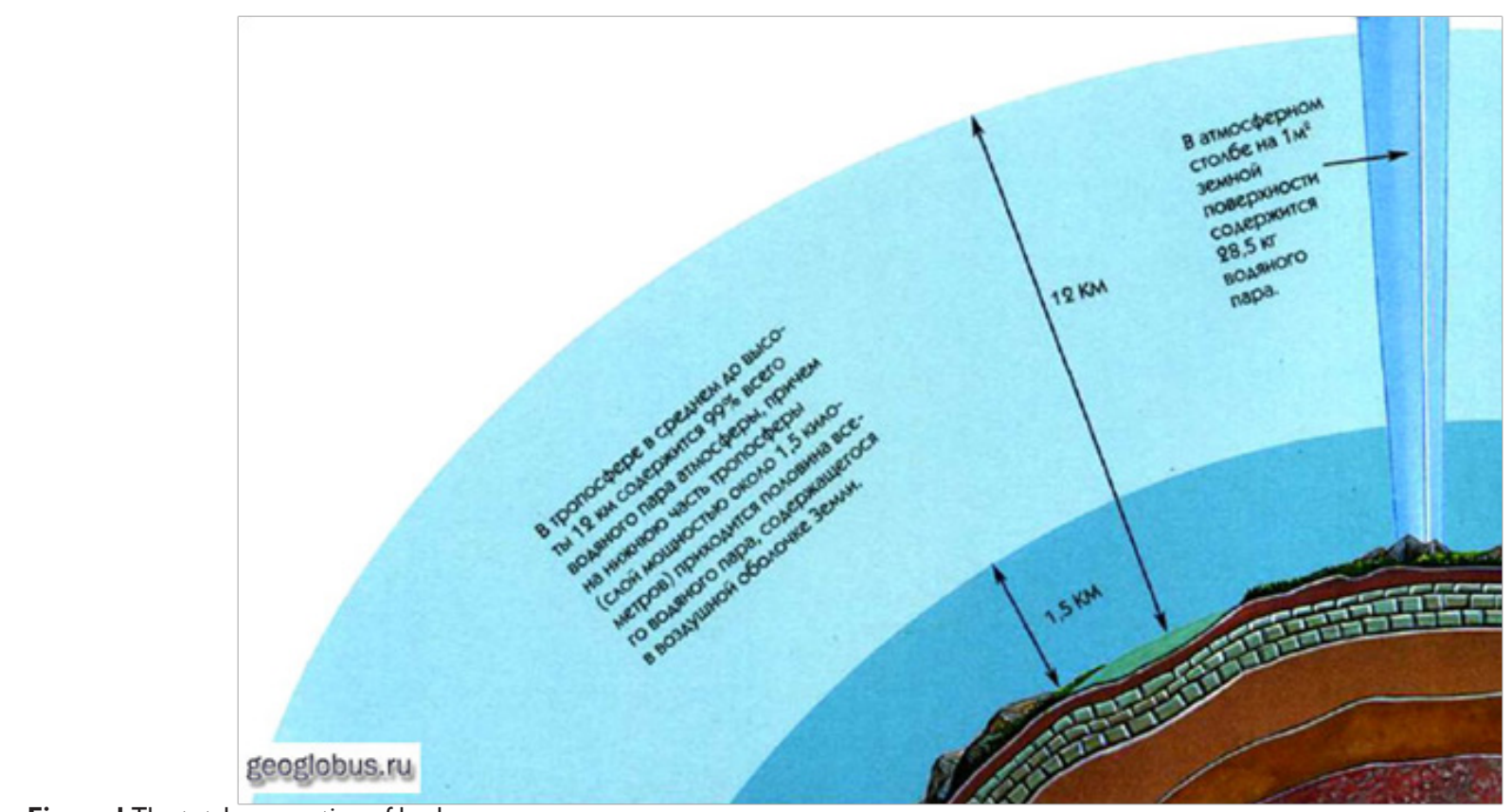

Figure I The total evaporation of land.

Began natural disasters, climate change. The growth of artificial vapors continues with the development of industry and our comfort. Moreover, this growth has a rather strong acceleration, as industrial and utility technologies develop and expand, increasing productivity in agriculture, mining, construction of cities and roads, and hydroelectric power plants with water accumulation in reservoirs.

Artificial evaporation has a speed greater than natural. In the soil, water spreads and accumulates by plant roots, microbes, worms, and exhales over time, in accordance with the properties of plants or living organisms. Each accepted portion of water passes, all stages of organic transformations of the body and goes with the distribution in time after a few days with breathing steam, secretions and transpiration of the plant. The water, which stood in a puddle on asphalt or heated in a kettle, leaves instantly in a few minutes. Consequently, artificial evaporation returns to the atmosphere much faster, and dense clouds hang over us almost continuously. We have rarely felt sunny days.

Analysis of natural disasters shows that there are areas of the planet where precipitations of unprecedented rainfall occur, leading to flooding. Conversely, areas that are not subject to precipitation for a long time - there are droughts and fires. Abnormal precipitations 
began to appear where they had never been - in the deserts. ${ }^{9}$ The usual rhythm was brought down: in the past three years, the rains in Atacame were frequent (March and August 2015, and then June 2017).

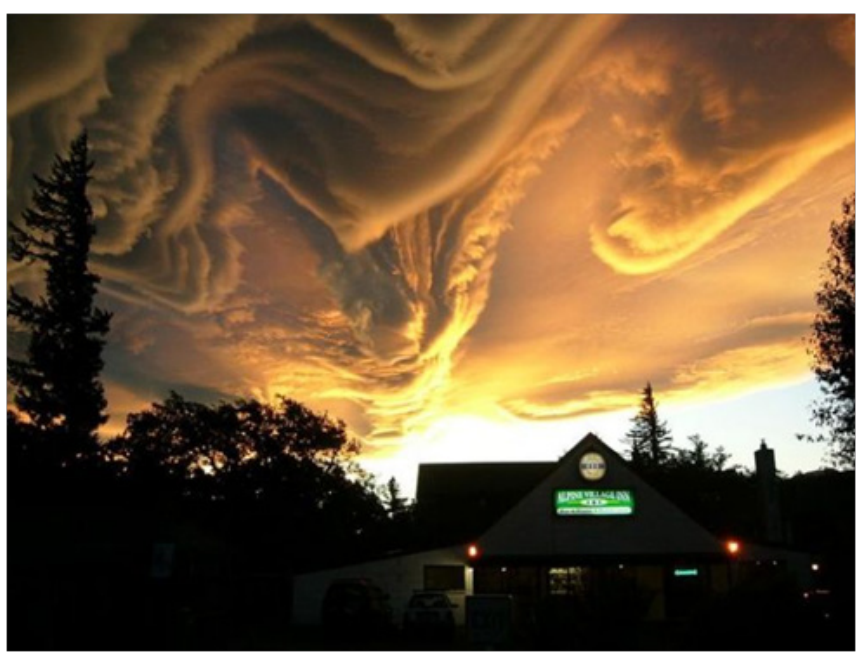

Figure $\mathbf{2}$ The growth of artificial vapors continues with the development of industry and our comfort.

The loss of stability in the distribution of precipitation by geographic location gives the right to think that the burdened clouds do not reach the polar and mountain glaciers and precipitate along the way. This explains the rise in ocean levels with a simultaneous decrease in glaciers. Thus, the quality, volume and speed of artificial evaporation broke the mechanism of water circulation valid for millions of years and lead to a global catastrophe.

If we want to leave our descendants a normal climate, then we must now begin to return nature to its organic evaporation and reduce artificial. To accomplish this, it is necessary to develop a new concept, a new strategy for saving the planet. The main focus of the concept should be the reduction of artificial vapors. It is assumed that it is not too late to start developing such a reduction. Here are a few of these elements.

The most wasteful evaporator is agriculture. Up to $9 \%$ of all fumes accounts for his case. Deep plowing of fields destroys underground living creatures - 20tons of it per hectare. Every organism, every stalk of biota has its own mode of water consumption. Dead arable land, especially during the non-growing season, without recycling water, returns it back to the atmosphere without organic transformations. Especially a lot of water is consumed in growing rice and cotton. About 1,350 billionm $^{3}$ of water is consumed annually in the rice fields of the world- $21 \%$ of the total water consumption for growing crops. ${ }^{10}$ "Global cotton production in the amount of 18 million tons per year implies the transfer of 100 billion tons of water". ${ }^{11}$ In the concept it is necessary to set tasks for replacing these products with others. For example, it is known that clothing can be made from wood, from artificial fibers. More important is the development of ways to reduce water consumption during cultivation. Barbaric irrigation methods based on irrigation systems, sprinklers are used. It has long been known and used drip irrigation methods. For example, in Israel and the United Arab Emirates. It is necessary to fully switch to these measures in all other regions. ${ }^{12}$ Drip irrigation is a method of irrigation, in which water is fed directly into the root zone of cultivated plants in small amounts controlled using dropper dispensers. Allows for significant savings in water and other resources (fertilizer, labor, energy, and pipelines).
Among the most destructive human activities on Earth in its relationship with water is hydropower. Developing alternative energy, following the recommendations of the Paris Agreements, we are building and launching new hydropower plants. They, from their reservoirs, raise into the sky new artificial vapors that harm the climate more than they give the benefit to man. Known non-pressure diversion hydroelectric. They are effective in mountainous areas, but such inventions are also known for plain places. With the possibility of using existing hydroelectric power plants with the release of reservoirs. In general, everything that concerns the accumulation of water, river turns, flooding of new territories is directed against nature. We must leave the existing rivers alone. At the same time, all the problems of trans boundary rivers will be removed.

A significant proportion of artificial evaporation occurs from flooding of coastal areas of rivers with flood waters. Rivers in constant motion wash off coastal particles and build up their bottom. Intensive economic activity human complements this process with its garbage. Increasing the bottom leads to an increase in the level of rivers and, with heavy rainfall, to the release of water from the banks. An urgent deepening of the river bottom is needed to eliminate flooding.

We spend very large volumes of water in everyday life. In this area it is necessary to revise all plumbing devices to reduce water consumption. For example, means are known for saving water by simple washing. Weusethisinaircraftandrailcartoilets.

There are a lot of such moments and take it over everything. A total saving of water consumption is needed in every enterprise, in every apartment, by all countries, by each person.

\section{Acknowledgments}

None.

\section{Conflicts of interest}

Author does not have any conflicts of interests

\section{References}

1. http://geoglobus.ru/earth/geo5/earth05.php

2. Half of the World's Annual Precipitation Falls in Just 12 Days, New Study Finds. Climate change on the environment.

3. http://ru-ecology.info/page/00307874802712200330005000049688/

4. http://www.refsru.com/referat-17732-3.html

5. http://jkg-portal.com.ua/ru/publication/one/globalna-posuha-aboproblemi-vodospozhivannja-32688.

6. http://www.kursach.com/geografiya-ekonomicheskaya-geografiya/816referat-gidrosfera-v-sostave-biosferi/view-details.html

7. http://geoglobus.ru/earth/geo5/earth05.php.

8. https://www.infoniac.ru/news/Samye-neobychnye-vidy-oblakov.html

9. http://www.nat-geo.ru/nature/1243703-anomalnye-dozhdi-unichtozhilimikrobov-v-pustyne/

10. http://ecology.md/page/rashod-vody-na-proizvodstvo-produkto

11. https://studopedia.ru/12_86797_proizvodstvo-hlopka-priumenshennom-rashode-vodi.html

12. https://ru.wikipedia.org/wiki/Капельное_орошение 